\title{
Spatial, Cultural and Historical Entities in Bačka
}

Besermenji, $S .^{*}$

\begin{abstract}
Spatial cultural-historical entities are urban or rural settlements of their parts. It is space with unmovable cultural goods with distinct cultural and historical values. This group of cultural goods is very numerous in this area of Bačka, and it is very convenient to tourist presentation and valorization. In Bačka these are old town cores, monasteries, rural environmental entities, cultural environmental entitiy of Palić Lake, Iodine Spa in Novi Sad and medieval fortification in Bač.
\end{abstract}

Key words Bačka, cultural-historical entities

\footnotetext{
Snežana Besermenji, University of Novi Sad, Faculty of Science, Department of Geography, Tourism and Hotel Management, Trg Dositeja Obradovića 3, 21000 Novi Sad, Serbia and Montenegro
}

\section{C} ultural values in Bačka are products of material and spiritual culture of different ethnic groups; fact that makes them even more attractive. Diversity of cultural heritage in Bačka represents a tangible tourist product. This kind of diversity in Bačka and Vojvodina is unique in whole Europe and that should be used as a symbol of cultural tourism in Vojvodina, as well as in Bačka. Rich history and numerous migrations made this region multiethnic; this characteristic is perfectly preserved in monumental fund, too. That is a unique advantage of cultural tourism in Bačka and it should represent a base for promotion of this region. Spatial, cultural and historical entities represent an important part of cultural values in Bačka. Law about cultural values defines spatial, cultural and historical entities as urban or rural settlements or their parts, i.e. an area with more immobile cultural values of a special cultural and historical importance (Group of authors, 1998). This group of cultural values is very numerous in the area of Bačka and is very suitable for tourist presentation and valorization. In Bačka those are: old city centers, Orthodox and Catholic monasteries, village ambi- ence entities, cultural and ambience values of Lake Palić, Jodna banja (health resort) in Novi Sad and medieval fort in Bač

\section{old City Centers}

Old city centers are favorite staying places for tourists, trade centers, cultural places, places to meet people and entertain. In Bačka there is a significant number of interesting and preserved old city centers such as those in Bečej, Sombor, Novi Sad and Subotica. They were formed at the end of $18^{\text {th }}$ and the beginning of $19^{\text {th }}$ century and are composed of institutions and buildings that belonged to rich people and officials.

\section{Novi Sad}

Novi Sad is a relatively young city whose existence goes back to the end of $17^{\text {th }}$ century when in 1748 it obtained the status of a Royal Borough by the decree of Maria Theresa. Today's name of the city goes back to that period and it means "new vineyard". As a small settlement, it used to serve for existential needs of Petrovaradin Fortress.

The very center of Novi Sad is represented by old city nucleus. Objects and complexes are under different regimes of protection. The area of the city centers is 4,0 ha.

The oldest part of the city is the area of Zmaj Jovina and Dunavska streets and the Square of Liberty. On old maps, the street was drawn as the first street leading from the city to the Lake Erzsebet, where Dunavski Park is situated today. Most houses in Dunavska Street were built at the beginning of $18^{\text {th }}$ century, and all of them are of great cultural, historical, and architectural value. Zmaj Jovina Street was called Main Street in the past and there was an open market in it. It was full of different shops and this characteristic was preserved up to the present time.

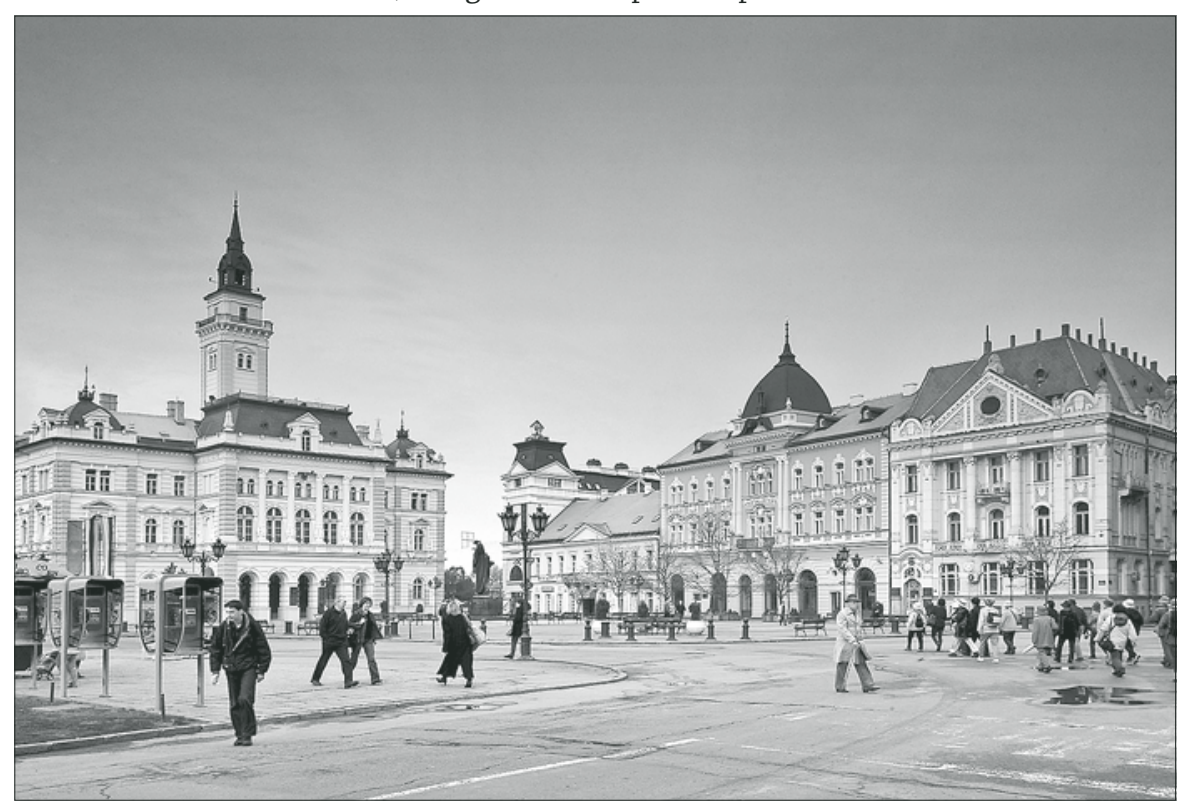

Plate 1. Novi Sad - Square of Liberty; photo: L.Lazić 


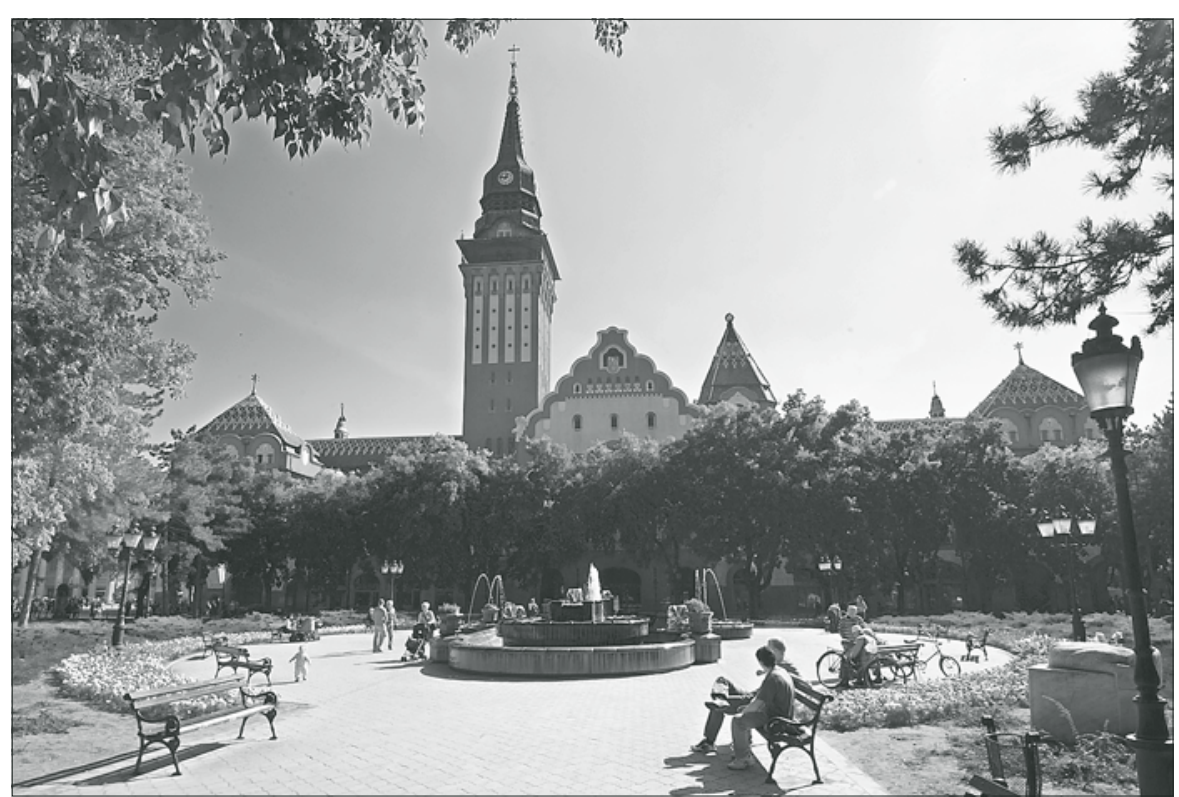

Plate 2. Subotica - City Hall; photo: L.Lazić

The area of the Square of Liberty came into existence in $18^{\text {th }}$ century, while buildings around it mainly date from the end of $19^{\text {th }}$ and the beginning of $20^{\text {th }}$ century. At the square there is a monumental statue of Svetozar Miletić. Ivan Meštrović made the monument, and it was built on the initiative of Matica Srpska and Democratic Party and it was put there in 1939. Buildings around the Square of Liberty are: Hotel "Vojvodina", Grand hotel "Majer", Magistrate-City Hall, Catholic Church-the Name of Mary, Bela banka.

\section{Subotica}

On the place of today's Franciscan monastery, there was a fort in the past. There was an intersection of roads in front of the south gate of that fort, and exactly on that place a new lengthy settlement was formed; settlement that did not essentially change urban matrix during period of time. The first written source from 1391, mentions town Zabotka, that belonged to Szeged sanjak until 1526. Evlija Čelebija distinguishes inner and outer town. In $18^{\text {th }}$ century it obtains the status of trade center, and at that time its name was St. Maria. It obtained the status of a Royal Borough in 1779 when it was called Mariatheresiopolis and at that time an intensive building of the city starts. City developed greatly when the railroad Szeged-Subotica was built in 1869.

In first decades of $19^{\text {th }}$ century, plans for the city structure were made, water currents were canalled, marshes were drained and works for regulation of streets were also carried out. The greatest number of buildings was built between 1880 and 1914, and the building works were approved by the Board for town embellishment.

Residential and business one-floor buildings were built in the central part of the city, while buildings with high ground floors were built on the outskirts. Public buildings usually had two or three floors. Architects Janoš
Škulteti, Titus Mačković, Ferenc Rajhl, Marsel Komor and Deža Jakab should be spoken about when mentioning building of this city. Janoš Škulteti drew up the plans for Theater and Ostojić palace. Titus Mačković drew up the plans for two palaces of Manojlović family, house of Golden melon and Trošarina. Ferenz Rajhl drew up the plans for Library, High School and family residential palaces. Marsel Komor and Deža Jakab drew up the plans for Synagogue, City Hall and Bank. Most buildings were built in secession style (group of authors, 1998, 81).

\section{Bečej}

Old city center of Bečej includes the area of central city square, which is called "pogača" (round bread), surrounded by neighboring streets. Historical nucleus of the city is defined with urban disposition and architectural valorization of the area and buildings. Physiognomy of old city center was formed during $19^{\text {th }}$ and in the first years of $20^{\text {th }}$ century. Central, flat, octagonal area of the
Plate 3. Sombor - Županija; photo: L.Lazić main Square was first paved with bricks, and since 1911 with asphalt. There is also public lighting since 1867, greenery that has changed its look during time and public monuments and buildings. Apart from a number of objects with monumental values, objects of special importance in the center are: endowment of baroness Jović, Serbian Orthodox Church, Roman Catholic Church, School of St. Sava, Library building and the Archive (Group of authors, 1998, 64).

\section{Sombor}

In the intersection of swamps and meanders of the Mostonga River, on one of the numerous islands, on foundations of medieval fort, the matrix of a later established city was repeated; settlement between trenches, with squared base, directions cardo and decumanus, whose look is confirmed by a plan from 1698. Two maps of Sombor from $18^{\text {th }}$ century show squared nucleus, i.e. inner town around which the city gradually expands and becomes of a star shape. On the plan from 1881, an unchanged, already formed matrix can be seen. City nucleus of Sombor, which is framed with four curved streets - Street of commander S. Stepanović, P. Bojović Street, Ž. Mišić Street and R. Putnik Street, is harmonious, homogeneous urban-architectural and cultural-artistic entity that developed continuously during two centuries. It had its peak in 1870s, when it enriched its heritage with building inheritance of baroque and classicism style, historic determination of eclectic with elements of neo renaissance, neo baroque, but also with examples of secession and modernism. Important buildings here are: Županija, City Hall, National Theater, City Library, Preparandija, Palace Krušper with tower, Palaces Gale, Grašalković, Lalošević and Konjović, churches of St. George, St. John, Holy Trinity and St. Ivan Nepomuk (Group of authors, 1998, 78).

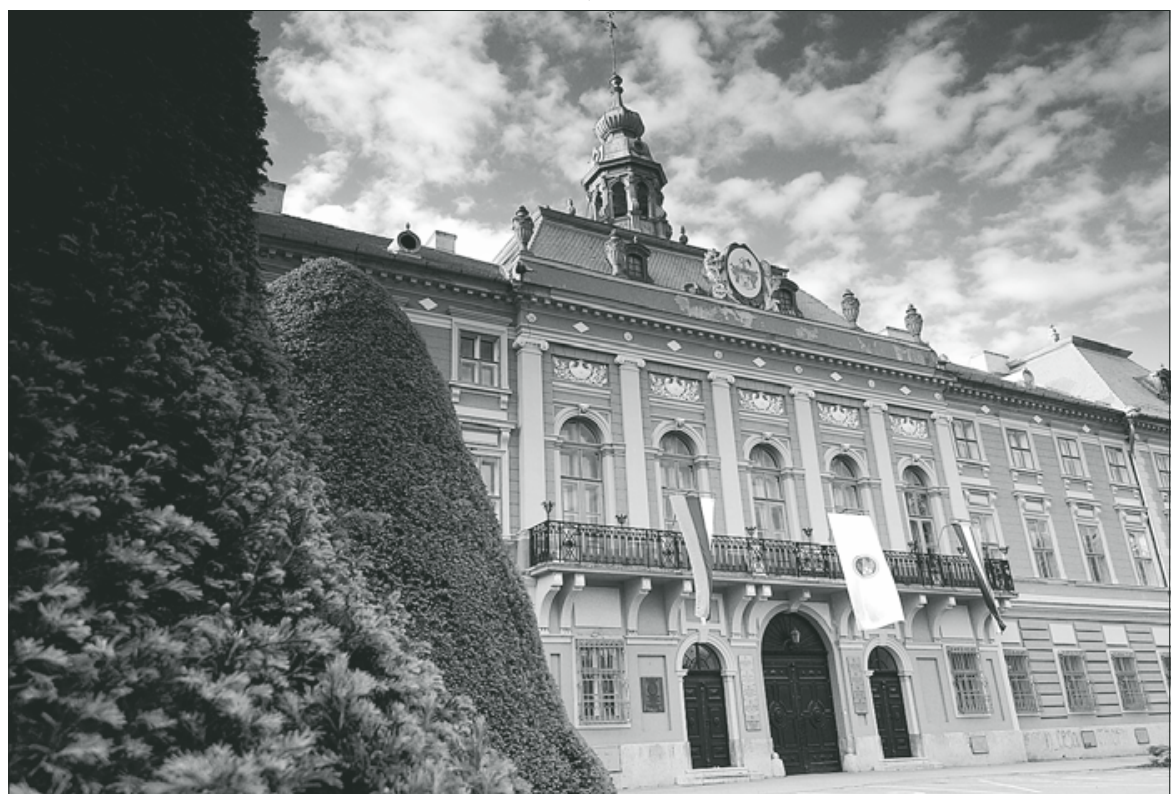




\section{GEOGRAPHICA ANNONICA}

\section{Monasteries}

On the territory of Bačka there is a great number of well-preserved Orthodox and Catholic monasteries. They represent very interesting objects from tourist aspect due to their artistic and cultural-historic importance. As cultural values, they attract a significant number of visitors of different structures and demands. That is why, in order to keep the level of dignity of these kinds of cultural values it is necessary to establish a certain regime, whether we talk here about organization of manifestations that can become chaotic or visits of school excursions. In Bačka, the following monasteries can be singled out according to their specificities and beauty: Kovilj monastery, monastery Bođani, Franciscan Catholic monasteries in Subotica and Bač

\section{Kovilj monastery}

This monastery is located on the riverbank of one Danube river branch. Today, the monastery complex consists of the church, one wink of monk lodgings, fence wall with the entrance gate and farm buildings. At present, the new monk-lodgings wing is being built and the workshop for making icons was opened in new and renovated part of the lodgings. Monastery church is devoted to St. Archangels, Michael and Gavrilo. It was made from stones from Fruška gora and it represents an interesting combination of old Serbian architecture and baroque. Iconostasis was painted by Aksentije Marodić in 1871. Today, Kovilj monastery is an active men's monastery.

According to the legend, the monastery was founded by St. Sava. However, the evidence shows that it was built in $16^{\text {th }}$ century. It was first noted in Turkish Cadastre paper in 1578 . Monastery was plundered and ruined for a few times. Thus, the first monk lodgings were built not earlier than in the first half of $18^{\text {th }}$ century and church was burnt and destroyed for several times.

\section{Bođani}

This monastery is in the southwest Bačka, 12 west from Bač. The church is devoted to the Non, sleeping of Holy Mother of God. According to legend, the monastery was built by the certain merchant from Dalmatia, Bogdan, whose eyesight returned with the help of spring water. The construction was finished in 1478 and the first written testimony on this monastery dates from 1540. The monastery was plundered in 1565 when Turks first tried to conquer Vienna. The new destruction of the monastery by the Turks happened in 1675 , and it was restored after whole three years. The church was burnt during the war between Austria and Turkey (1695). In the Rakochi Uprising in 1705 , the monastery was plundered and looted again, and, not long after, in 1711 it was seriously damaged in a flood from Dan-

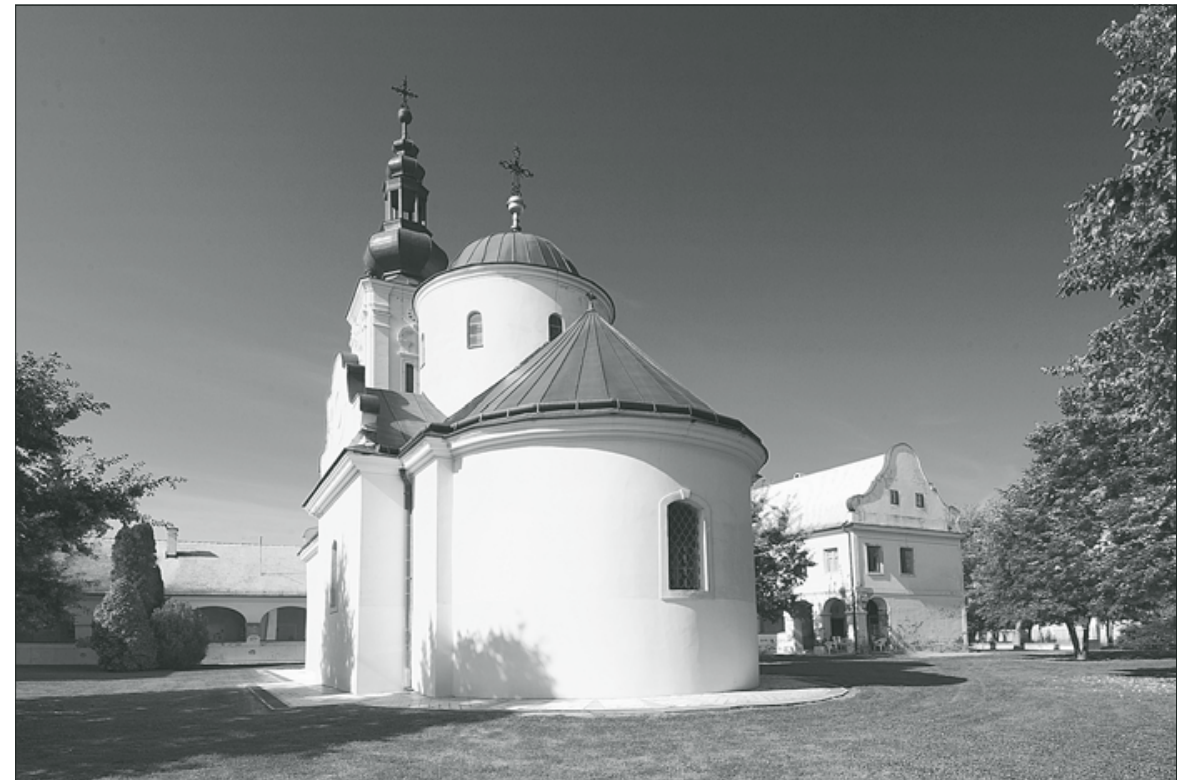

Plate 4. Bođani monastery; photo: L.Lazić

ube. In 1722, building of the fourth church started. The benefactor was certain Mihailo Temišvarlija from Szeged. The new church was painted by Hristof Žefarević in 1737, who introduced some new elements of baroque style. Ikonostasis was painted by Russian icon painters Vasilije Romanovič and Jov Vasiljevič in $18^{\text {th }}$ century. At that time, the monk lodgings and the belfry were also built in baroque style.

The monastery was damaged in a fire in 1755 and 1785. Between 1787 and 1790 the more detailed restoration and reconstruction of the monastery complex was done. New floors were built on the old foundations of monk lodgings. In 1797 the chapel was built over the spring on which Bogdan cured his eyes. During I World war, Austro-Hungarians took the two bells to forge cannons.

The monastery was completely repaired between 1970 and 1974 and today, it belongs to one of the best organized monasteries. There is a school for icon painting and in one part of the monk lodgings the Memorial Museum of Hristof Žefarević was opened, with all his works and other church and artistic valuables. In the monastery park there are over 130 plant types (Group of authors, 2002).

Although it is very attractive, this monastery is not visited by many tourists, mainly because of its peripheral position.

\section{Franciscan monastery in Subotica} Franciscan monastery and its church in Subotica are devoted to St. Michael, and they are situated on the place of the old for tress, that was built in 1439. That fortress was for a long time one of the most important strategic points in a battle against Turks. The remains of the fort can still be seen on the wall of east church belfry. In 1730, the monastery was given to Franciscans and since then they run it. In the same year a new church was built when a chapel was widen. Franciscans established the chapel in 1695 in a large hall in the ground floor of Subotica tower. The monastery building has ground floor and first floor, which form spacious atrium of rectangular base. Along both levels there are halls with spherical ceilings. There is no decoration on the facade, which is usual for residential objects of Franciscan monastic order. The only exception is cordon wreath that separates walls into two parts. The monastery when a new belfry was built. There are plenty of art works in the monastery, mostly paintings. The halls on the first floor are decorated with 46 oil paintings, and in the separate monastery Chapel the painting of Dark Lady is kept. The painting is probably the work of one painter from Venice and is considered to be the copy of Madonna from Chenstahov in Poland.

The first elementary school in Subotica was opened in the monastery in 1731, in 1747 the first secondary school was opened, and some time later an advanced school of rhetoric and philosophy. Due to an educational activity of this monastery, the decision of Emperor Joseph II to close all Franciscan monasteries was not carried out (Municipal institute office for protection of monuments of culture in Subotica).

\section{Franciscan monastery in Bač}

Complex of Franciscan monastery consists of the church, the belfry and monk lodgings. The church and the belfry were built in $12^{\text {th }}$ century and they represent the only medieval church and belfry in Bačka. Because of that, the monastery is protected tance.

The catholic monks from the order St. Jerusalem Grave founded the monastery of St. Mary at the time of the Crusade. The monastery chronicle notes 1169 and 1188 as the years when the building of the church and the belfry was finished. They were built was completely repaired in 1907 and 1908, as the cultural monument of great impor- 


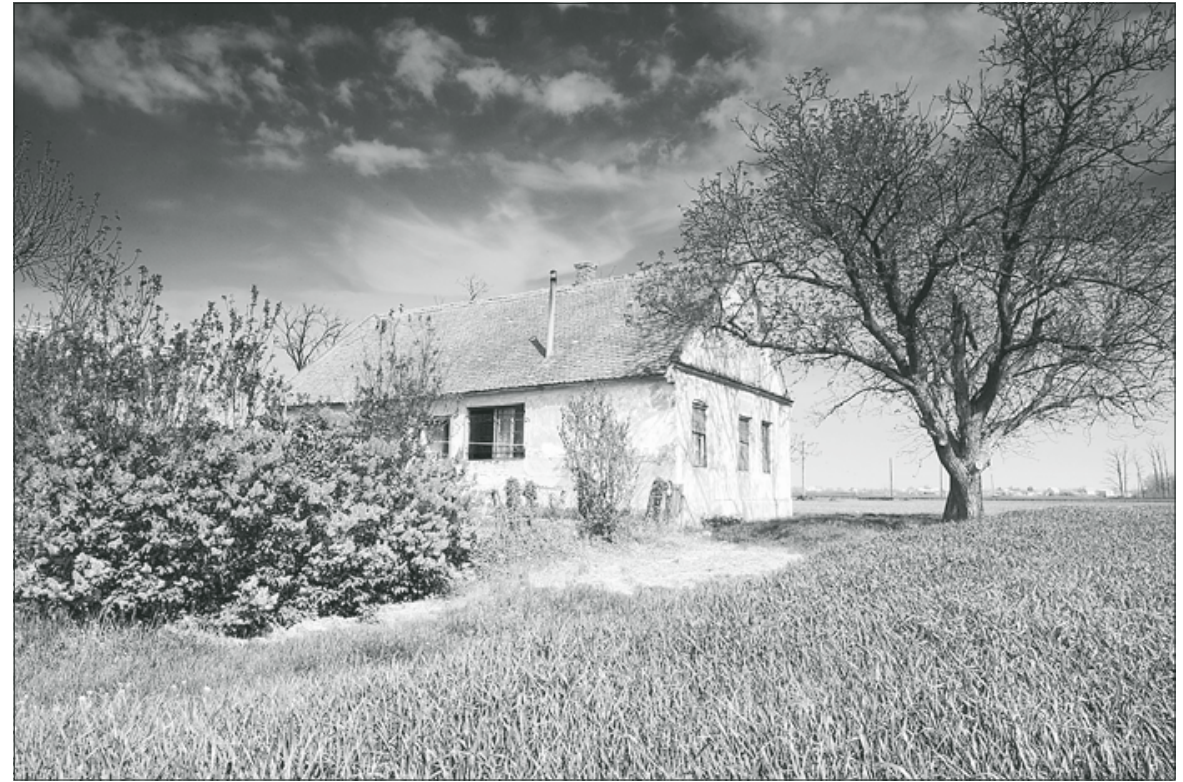

Dlate 5. Farm (salaš) in Čenej; photo: L.Lazić

in Romance art period. The present architectonic form of the whole monastery is a mixture of different styles, above all - Romance, Gothic and Baroque (Group of authors, 2002).

The most precious part of the monastery is its church, i.e. its apse built in Romance style and made of bricks and cut stone. Nave of the church is covered in crossshaped arches. West trave with a choir was added later, and niche on the south wall dates from the Turkish period. At the time of Turkish siege of Bač, the church was damaged, and after that it was turned into a mosque. The "mihrabe" on the south church wall and the water jug with Turkish ornaments dates from that period. On the south wall of naos, in an area in front of the altar, two fragments of gothic biographies were discovered. On one of them two heads are shown and on the other, bust of a man's figure with a crown, which is wrapped with ornaments with grapevine motifs. Fragments of architectural plastic on facades point to influences of late Gothic. On the eastern side, next to apse, there is a massive belfry (Jovanović, 1973).

In the monastery dining room, on the east wall there is the painting Last Supper from 1737, painted in baroque style. Besides italocrete icon of the mother of God, painted by Dumas (1683), the monastery keeps many manuscripts and books from $17^{\text {th }}$ and $18^{\text {th }}$ century (Sevdić, 1957).

\section{Village ambience entities}

Ambience and physiognomy values of today's Bačka villages date back from $18^{\text {th }}$ century, when these villages started to be built by plans and certain rules. At that time, people started building houses according to strict standards because they were built on regulating street lines. First colonist houses were made of two rooms, with a small kitchen and a big room. The roof was covered with reed. On the yard side, there were deep eaves as the antecedent to porch. First houses were partly dug in the ground. These kinds of two-part of houses became three-part by adding one more room. As the economic power of their owners grew, houses became even larger, especially in the second half of $19^{\text {th }}$ century. By adding new premises along the street line, houses in Bačka were built with the full yard front (Đekić, 1994).

Besides basic rooms for living, some farm additional buildings are also built, which tell us about the way of making living during $18^{\text {th }}$ and $19^{\text {th }}$ century. Those are mainly barns and windmills, which are protected today because of their historic value.

The most attractive forms of village architecture in Bačka are: houses in Bački Petrovac (B. Mokić St. No. 7-9), house in Bačka Topola (Moše Pijade St. No.19), house in Ruski Krstur (Marshal Tito Street) and house in Vojka (Marshal Tito St. No.41). All houses mentioned are monuments of great importance and are under state's protection. Barns in Golubinci and Stapar belong to the group of remarkable cultural monuments, and they represent masterpieces of woodcarving.

In Bačka there are also objects under the third level of protection. Among them, of special value is hemp factory in Bački Petrovac, with wooden mechanism for processing hemp from 1864.

In order to preserve ambience and architectural values of villages in Bačka it is necessary to create ethno parks, that would be based on ICOM Declaration from 1957. They would represent open-air museums and contain many examples of national architecture, relocated from their original places. Rural architecture and village ambience in Bačka is especially interesting because Bačka is a homeland of a large number of ethnic groups, that are unique and have original and recognizable folklore.
Formation of ethno parks would be a good solution to provide their protection and presentation. In Bačka there is no single park with clearly expressed tourist function.

\section{Farms in Subotica and Sombor (Salaši)}

Rural architecture in North Bačka has certain special characteristics compared to other regions in our country. Preserved farms, that represent cultural-ambience special feature of Pannonian soil, are characteristic for that region. These kinds of farms are a primitive form of agricultural settlements. Those are lonely residential objects with accompanying farm buildings in the yard. Whole families used to live on those farms. They were occupied only with agricultural manufacture, so they kept their agricultural products, machinery and cattle on those farms.

Following farm settlements are to be found in the vicinity of Sombor: farms in Bezdan, Gradina, Đurđin, Žarkovac, Lugumirci, Materići Milčići, Nenadić, Obzir, Radojevići, Rančevo and Šaponje. These farms are characterized by a constant fall of the number of inhabitants. In 1962 there were 1595 households and 5492 inhabitants. According to the roll from 1991 there were only 791 households and 2401 inhabitants. According to the research of Silvija Loča (2000), in 1999 there were 702 households and 2180 inhabitants (Romelić, Tomić, 2001, 68).

Farm objects in the vicinity of Sombor represent specific and important potential for activation in tourist purposes. Thus, certain number of objects would be revitalized and that would stop their fading away. Multidisciplinary engagement of specialists is necessary in order to optimally carry out the tourist valorization. They would make a spatial plan, that would, apart from commercial importance, represent a base for the reconstruction that would preserve the authentic ambience.

\section{Farms in Čenej (Salaši)}

Farms in Čenej belong to the municipality of Novi Sad and cover an area of 9423 hectares. They were formed by grouping of farms on different locations, mainly, along the road Bački Jarak-Zmajevo, as well as when by their grouping around the church in Čenej.

Farms in Čenej are placed on the south Bačka wattle terrace, on one noticeable slope, that goes from northwest to southeast. They are placed in chernozem zone, famous for its great fertility. The most frequent winds are: north wind, southeast wind and west wind, that can blow here at even $100 \mathrm{~km} / \mathrm{h}$, which had a great influence on the orientation of residential and accompanying objects on farms. That is why 
those objects are placed with their narrower side towards wind "on furrow".

It is difficult to give their exact number, because the situation changes quickly. Between two World Wars there were about 440 farms and more than 2000 inhabitants. According to some sources, today there are 237 active farms.

According to their location and payment, farms in Čenej can be divided into three groups. Lonely farms, around which there are no other farms on greater distances but only land that owners cultivate belong to the first group. The second group is represented by farms that are placed without any order, and which usually appeared as the result of family division or land sale. In that way, land lots were made smaller and new farms were built on much smaller distances between them. The third group is represented by those farms that are placed according to some kind of order, for example, in one row and on small distances between them or by their grouping along the one side of the road, that connects Čenej with other places.

Farms in Čenej are unique in their own way and deserve tourist presentation with a certain correction. Today, certain farms are equipped to welcome guest with higher means of payment.

\section{Specific ambience character of villages Bački Monoštor- \\ Kupusina-Sonta}

In Western Bačka there is a marsh-pond ecosystem, known as Special Nature Reserve "Gornje Podunavlje", whose integral part are villages Bački Monoštor, Kupusina and Sonta. Ambience features of those villages, as well as in other parts in Bačka, i.e. Vojvodina, date back to the time of colonization of Franc Joseph and Maria Theresa. In this particular area a great number of authentic houses from this first colonization have been preserved. Those first colonist-houses are made of mud and straw, their gables face the street and the roofs are made of reed. Monoštor is most north of the three, and it is a village similar to any other village in Bačka, but with a very well preserved tradition. Few tens of old houses that are traditionally furnished have been preserved. Original architecture is even better preserved in Kupusina, because in some parts it reminds of a well organized ethno-park. About a hundred old reed-houses, as well as about forty chapels and statues of religious contents, that are placed all over the village, represent the village ambience of $\mathrm{Ku}$ pusina. The most attractive part of Sonta is Kajmakčalanska Street with a larger number of authentic houses.

In the last couple of years, a traditional part of Bački Monoštor and Sonta was greatly devastated when new objects were built, fact that tells us that the inhabitants

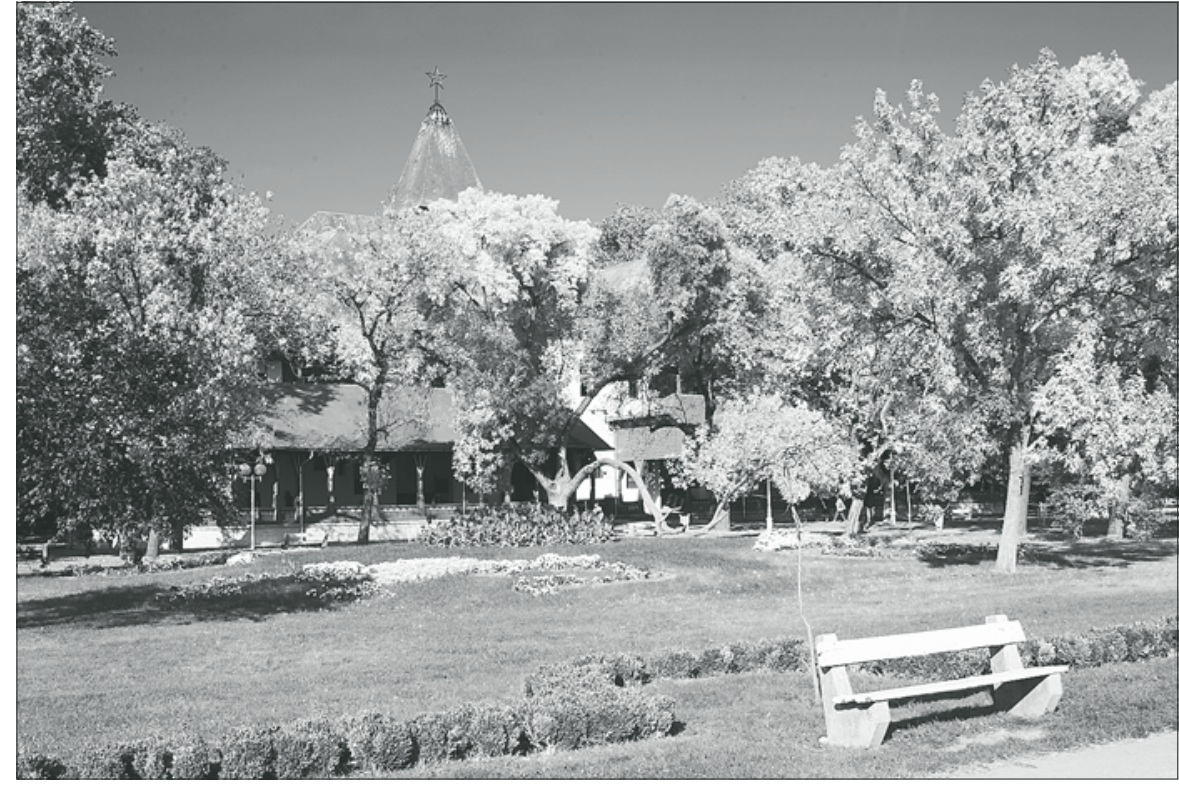

Plate 6. Lake Palić - Big Terrace; photo: L.Lazić

are not motivated to preserve their own tradition. This kind of phenomena directs tourist and cultural practice to the action in order to preserve the remained parts of traditional settlements, where rural tourism could be developed. Tourist content of these kinds of ambience entities can be very heterogonous (Group of authors, 2002).

\section{Cultural and ambience entity of Lake Palić}

Lake Palić is situated in natural depression, east from Subotica. The attractiveness of Lake Palić is extraordinary because it represents the combination of natural and cultural values. It is the biggest lake in Bačka, and it covers the area of $5,76 \mathrm{~km}^{2}$. It has the shape of the crescent that spreads the branches towards west and north. There are Big Palić and Small Palić. Wider, north part represents Big Palić, and narrower, western part Small Palić. The width of the lake is from $350 \mathrm{~m}$ to $825 \mathrm{~m}$, and its length is $8250 \mathrm{~m}$. The water depth is from $1,5 \mathrm{~m}$ to $2 \mathrm{~m}$, and the lake bottom is flat.

Lake Palić became especially attractive; both as a bathing and rest resort in the middle of $19^{\text {th }}$ century, when a railway line Subotica-Szeged was opened. The plan how to parcel out the area west from the park was made in 1853 and that is the place where first villas were built. The building of summerhouses continues also along the east side of the park. After the lakeshore was protected, the swamp west shore was also parceled out and the building of objects, which are today an important element of Park of nature "Palić", started. The most important buildings are: Water tower, Big Terrace and Women's Strand.

Water tower was built in 1909, as a functional object as part of water supply system. It was built in a form of ornate village gate, in secession style. It is made of two architectonic entities, the cone-shaped tower and the circular pavilion. Those two parts are con- nected by a wide arch through which the view goes all the way to the lake, via the alley, to the lake itself, i.e. to the memorial fountain (Martinović-Cvijin, 1988). When it was built, the tower was a reservoir, tram stop and a luxurious triumphal arch of the main entrance. Because of its attractiveness, this object represents the symbol of Lake Palić.

The Big Terrace represents the central object in the Palić promenade. It was built in 1912 in secession style and it had catering facility. The ground floor was intended for parlor, café and restaurant, and the first floor was supposed to be for parties and balls. Because of the great attractiveness of this object, the restoration of the façade was also done. It would be necessary to redecorate the closed inner part of the terrace and bring it back its former usage. In the neighborhood of the Big Terrace there is a musical pavilion, also built in secession style. From it, the orchestra played promenade music.

The third object, built in secession style is Women's Strand, that is placed on the north bank of the lake, near the Big Terrace. This building is completely made of wood, and it was built on logs that were stuck in a coastal shallow belt. From only practical reasons, this building was made in "piledwelling" style, in order to make it possible to cross the mud that was to be found along the coast. Woman bathers were protected from curious looks with attractively ornamented, wooden cabins. Today, during summer season, these cabins are rented to members of the club "Woman's Strand".

On the wider area of Palić, a whole row of villas and summerhouses that contribute to the ambience entity of Lake Palić was built. Villas that are specially noticeable because of their beauty, and which are located in Park of nature "Palić" are villa "Blizanci", villa "Lujza", villa "Vermeš", as well as summerhouse in "Splitska aleja" Street. All these objects are protected. 


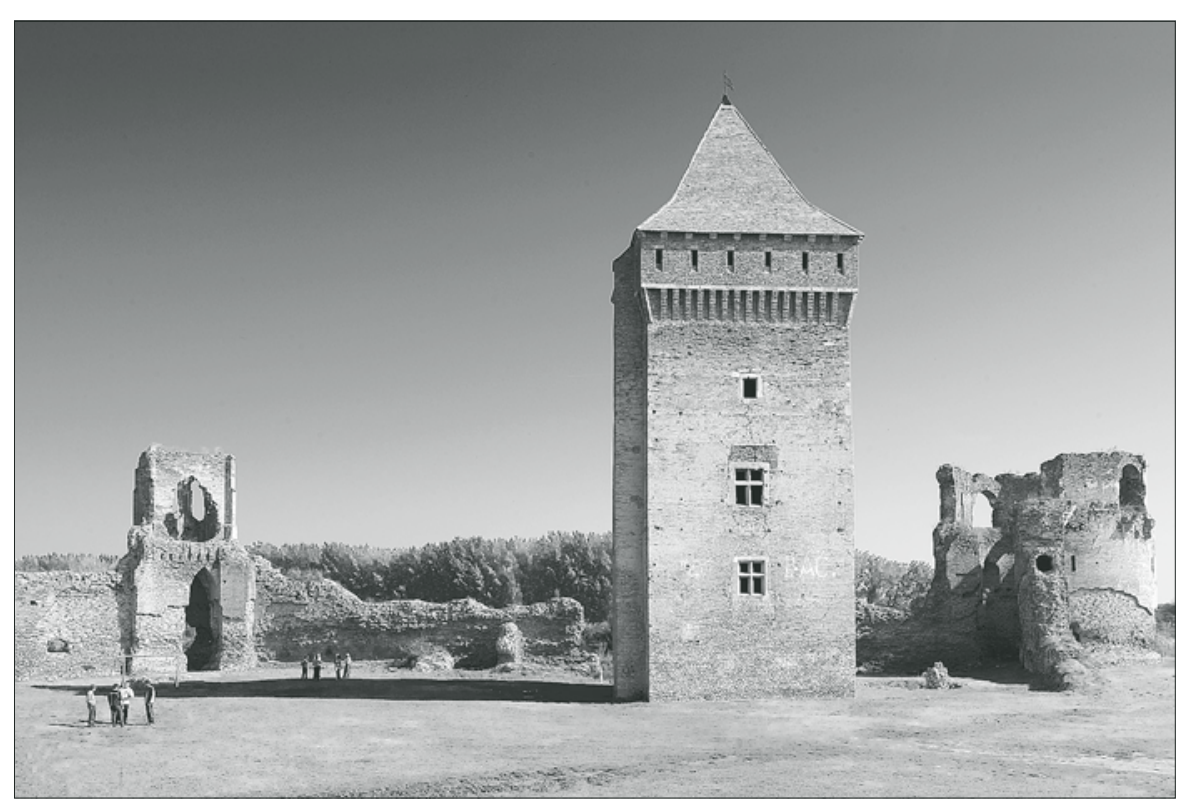

Plate 7. Mediavel fort in Bač; photo: L.Lazić

Ambience value of Lake Palić is emphasized by the presence of the park, that stretches along the north coast of the lake, and that covers 18 ha. Park was built in 1842 in English style, that was at that time very popular in garden architecture. English (landscape) style is characterized by winding walking paths and greenery compositions, that resemble freely formed groups in nature. They bring into reality socio-cultural, microclimatic and ecological function. Park was renovated in 1911, in baroque style. Geometrically shaped walking-paths and symmetrically shaped flow er alleys were made then. High greenery in the park is of different kinds, and there are about 45 different sorts. Seasonal flowers and perennial is grown in the park, too. Park is nicely arranged and well taken care of. In the former main street of Palić bathing resort (today's "Splitska aleja") a line of plane-trees was built, that is now over a hundred years old.

\section{Jodna banja (health spa) in Novi Sad}

Health spa (Jodna banja) in Novi Sad was opened when hot water was discovered after the artesian well was built in 1897 98. When objects that serve the function of the health spa and the park were built, spatial cultural-historical entity was formed, and is treated as a cultural value of great importance.

Private joint-stock company with their manager Vilt Wilhelm started the building of iodine health bath in 1906 . The bath was built according to the plans of Imre Franček in Futoški Park, that resembled an English park. Main and yard facade have a representative outlook. Rich, plastic decorations contributed to that. The main entrance is especially richly ornamented with plastic decorations, that represent atik with oculus that is framed with a wreath, two nymphs and fishes. Above the central part of the build- ing there is a four-sided dome with a lantern, flanked with two smaller, finished profiled sharp ends. Complex base is in a shape of letter T. The building with a swimming pool in it has a high ground and rectangular base, leaned on the middle part of the backside of the bathhouse. Today, three wards of the Institute of medical rehabilitation, Faculty of Medicine, Novi Sad are placed here (Group of authors, 1998, 75).

\section{Medieval fort in Bač}

The medieval fort in Bač was first mentioned in 1192. It was the time when most forts in the Danube basin were built. Even the Pope Inocent IV, encouraged by the wish of Hungarian King Bella IV, sent a letter to the Bishop of Bačka with the suggestion to help the building of the fort in Bač. Some sources claim that that in the city center there were Cathedral and the Bishop's office. The present remnants date from $14^{\text {th }}$ and $15^{\text {th }}$ century (Sekulić, 1979).

The fort was situated in the meander of the river Mostonga. Town consisted of the fort and the lower city built on a rather small river island. It was built with bricks, and stone was used only for certain elements. The base of the fort is of very irregular rectangular shape whose longest south side is broken somewhere in the middle. Circular or square towers were situated on the corners. In front of the entrance gate there was a defense tower that was connected with the construction of the entrance gate by the bridge. Closer to the southeast corner there was a powerful and high defense tower. The fort was renovated and strengthened in renaissance style at the end of $15^{\text {th }}$ and at the beginning of $16^{\text {th }}$ century, when it was under the authority of Petar Varadi and Pavle Timori. That is the main and at the same time the biggest fort in Bačka. Since 1958, archeological excavations have been done for a few times. Works were done on the restoration of de- fense tower and the conservation of the entrance gate (Group of authors, 1998).

\section{Conclusion}

In Bačka, cultural goods represent creation of material and spiritual culture of distinct ethnic groups. This is why they are becoming more and more popular, and they represent tangible products of tourism. As a very significant part of cultural goods of Bačka, spaces of cultural historical entity are very convenient to tourist presentation. These are: old town cores, monasteries rural environmental entities, cultural environmental entity of Palić Lake, Iodine Spa in Novi Sad and medieval fortification in Bač.

\section{References}

Grupa autora (1984): Stari čenejski salaši 1237-1945. Vojvođansko društvo za poljoprivrednu tehniku, Novi Sad.

Grupa autora (1998): Spomeničko nasleđe Srbije, Nepokretna kulturna dobra od izuzetnog i velikog značaja. Republički zavod za zaštitu sopmenika kulture, Be$\operatorname{ograd}(59,61,83)$.

Grupa autora (2002): Kulturna dobra u turističkoj ponudi Vojvodine. Prirodnomatematički fakultet, Departman za geografiju, turizam i hotilejijerstvo, Novi Sad (90).

Sevdić J. (1957): Lokaliteti fresaka u Vojvodini, Građa za proučavanje spomenika kulture Vojvodine I. Zavod za zaštitu i naučno proučavanje spomenika kulture Autonomne pokrajine Vojvodine, Novi Sad (33).

Sekulić A. (1979): Drevni Bač. Zbornik "Kačićc, Split.

Jovanović S. (1973): Franjevački samostan u Baču. Zbornik Zaštite spomenika kulture XXII/XXIII, Zavod za zaštiti i naučno proučavanje spomenika kultrure Sr Srbije, Beograd (132).

Medović P. (2000): Praistorija na tlu Vojvodine. Novi Sad.

Milanović-Jović O. (1982): Arhitektura Starog jezgra Novog Sada. Građa za proučavanje spomenika kulture Vojvodine XI-XII. Zavod za zaštitu i naučno proučavanje spomenika kulture AP Vojvodine, Novi Sad.

Međuopštinski zavod za zaštitu spomenika kulture Subotica

Romelić J. Tomić P. (2001): Mogućnosti i značaj turističke valorizacije salašarskih objekata u okolini Sombora. Ruralni turizam i održivi razvoj Balkana, Prvi forum. P.M.F. i Ekonomski falultat, Kragujevac.

Đekić M. (1994): Kuća kao spomenik kulture. Narodno graditeljstvo Vojvodine, Novi Sad.

Zavod za zaštitu spomenika kulture Vojvodine

Međuopštinski zavod za zaštitu spomenika kulture Subotica 